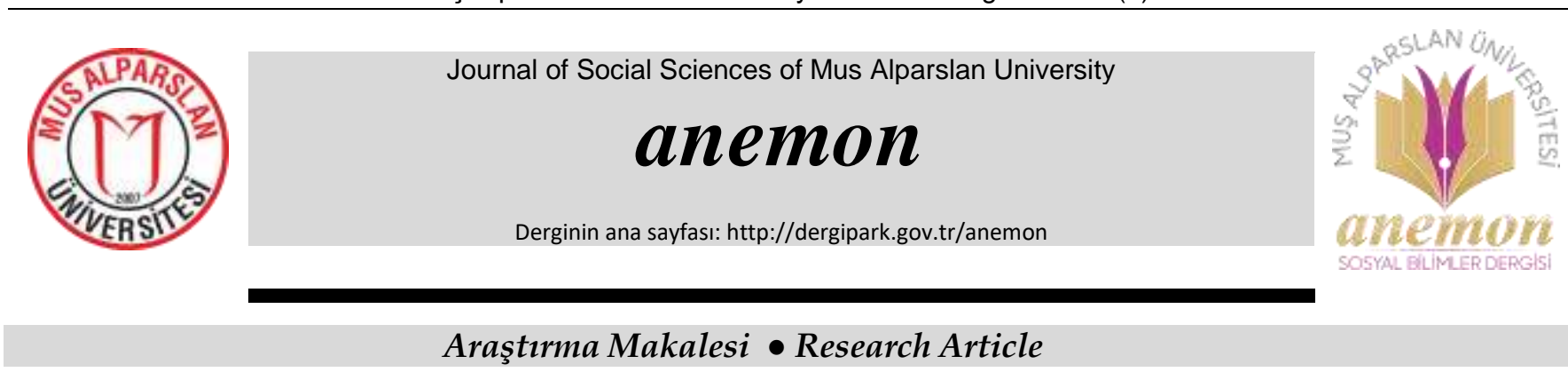

\title{
Sosyal Sağlık Bileşeni Olarak Sosyal Destek ve Ailenin Rolü
}

\section{Social Support as A Social Health Component and The Role of The Family}

\author{
Recep Yıldız ${ }^{\text {a,* }}$, Yasin Erdurak ${ }^{\mathrm{b}}$ \\ ${ }^{a}$ Doç. Dr., Bandırma Onyedi Eylül Üniversitesi, Sağlık Bilimleri Fakültesi, Sosyal Hizmet Bölümü, 10200, Bandırma/Türkiye. \\ ORCID: 0000-0003-0584-6649
}

b Öğr. Gör., Bandırma Onyedi Eylül Üniversitesi, Sağlık Hizmetleri Meslek Yüksekokulu, Sosyal Hizmet ve Danışmanlık Bölümü, 10200, Bandırma/Türkiye ve Doktora Öğrencisi, Yalova Üniversitesi, Sosyal Bilimler Enstitüsü, Sosyal Hizmet Anabilim Dalı, 77200, Yalova/Türkiye ORCID: 0000-0003-0949-8100

\section{MAKALE BİLGİSI}

\section{Makale Geçmisi}

Başvuru tarihi: 1 Kasım 2020

Düzeltme tarihi: 19 Ocak 2021

Kabul tarihi: 1 Şubat 2021

$$
\begin{aligned}
& \text { Anahtar Kelimeler: } \\
& \text { Sosyal Sağlık } \\
& \text { Aile } \\
& \text { Sosyal Destek, } \\
& \text { Sorunlarla Başetme }
\end{aligned}
$$

\section{A R T ICLE INFO}

\section{Article history:}

Received: November 1, 2020

Received in revised form: January 19, 2021

Accepted August: February 1, 2021

\section{Keywords:}

Social Health

Family

Social Support

Coping with Problems
ÖZ

\begin{abstract}
Toplumsal ilişkilerin ve etkileşimlerin sürdürülmesinde yapı taşı olarak nitelendirilen aile, bir aracı kurum olarak vazifesini sürdürmektedir. Çalışma sosyal sorunlarla baş etme kapasitelerini kullanarak toplumsal iyilik halinin sağlanmasında ve/veya sosyal sağlığın korunmasında ailenin etkin aktör olarak konumunu belirlemeyi amaçlamaktadır. O nedenle sosyal sağlığın bileşeni olan sosyal desteğin aile kurumundaki değerine dikkat çekmektedir. Çalışma söylem analizi yöntemi ile gerçekleştirilmiştir. Sosyal sağlık ve sosyal destek alanındaki literatür çalışmaları incelenmiş ve aile bağlamında ilişki düzeyi ortaya konmuştur. Çalışmada, bireylerin tam bir iyilik halinin sağlanması, baş etme kapasitelerinin güçlendirilmesi ve sosyal işlevselliklerinin kazanımında rol üstlenen sosyal sağlık için sosyal desteğin etkin bir araç olduğu ortaya konmaktadır. Aile ve üyelerince sunulan sosyal destek ise sosyal sağlığa en etkin katkının adresidir.
\end{abstract}

\section{A B S T R A C T}

Described as a building block in maintaining social relations and interactions, the family continues to serve as an intermediary institution. The study aims to determine the position of the family as an active actor in ensuring social well-being and / or protection of social health by using their capacities to deal with social problems. Therefore, that draws attention to the value of social support, which is a component of social health, in the family institution. The research was carried out by discourse analysis method. Literature studies in the field of social health and social support were examined and the level of relationship in the family context was revealed. The study reveals that social support is an effective tool for social health, which plays a role in achieving the full well-being of individuals, strengthening their coping capacities and gaining social functionality. Social support also offered by family and members is the address of the most effective contribution to social health.

\section{Giriş}

Sağlık, fiziksel, psikolojik ve sosyal bileşenlerin tümünü içermektedir. Bu bileşenler, en başta sosyal çevre olmak üzere bireysel, grupsal ve toplumsal güçler tarafindan şekillenmektedir. Araştırmacılar tarafindan toplumsal hayat, -bireyin ve genel anlamda toplumun sosyal iyilik hali, sosyal destek, sosyal işlevsellik gibi- "sosyal" i içeren terimlerle ele alınmaktadır. Bu bağlamda sağlı̆̆ı, sadece sağlıklı olma hali, hasta olup olmama durumu, iyileşme ya da iyileşememe $v b$. durumlarla sınırlandırmadan çok boyutlu değerlendirmek zarurettir. İnsanın biyo-psiko-sosyal varlığının kabulü, sağlığın sadece biyolojik/fiziksel açıdan değil aynı zamanda psikolojik ve sosyal olarak ele alınmasını da zorunlu kılmaktadır.

Medikal ve tıbbi olanın önemi, bireylerin hastalıklarının iyileştirilmesinde ve hastalıklarına ilişkin tedavi edebilecek ilaç gibi araçların bulunmasında görülmektedir. Tedavi

\footnotetext{
*Sorumlu yazar/Corresponding author

e-posta: ryildiz@bandirma.edu.tr
} 
edilen her birey, bu sürecin bir kazanımını göstermektedir. Ancak ilaçlarla hastalığın biyolojik/fiziksel tedavisi yanında bireyler için bu yaşantı sürecinde aile, akraba, arkadaş gibi sosyal destek mekanizmalarının varlığı da göz ardı edilmiş değildir. "Sosyal sağlık" kavramı da bu düşüncenin bir ürünüdür.

Literatürde ortak bir sosyal sağlık tanımı bulunmamaktadır. Türkiye'de genellikle sosyal hekimlik, toplum hekimliği ve toplum sağlığı üzerinden konuya yaklaşılmaktadır. Batılı kaynaklarda ise genellikle sağlığın sosyal bileşenleri ya da belirleyicileri üzerinde durulmaktadır. Sosyal sermayenin bileşenleri olan sosyal ağlar, normlar ve güven bileşenleriyle de açıklanmaya çalışıldığı görülmektedir.

Tanımlamaların iki ortak noktası vardır denilebilir: Birincisi, sosyal sağlığın bireylerin, grupların ve toplumun tam bir iyilik halini içermesi; ikincisi, iyilik halini gerçekleştirmede kullanılan araçların/odakların belirtilmesidir. $\mathrm{Bu}$ araçlar sosyal destek, sosyal işlevsellik, sosyal bütünleşmedir ki birey odağında sorunların çözümüne ve sorunlarla başetme kapasitesinin güçlenmesine dair kazanım sağlamaktadırlar.

Bu çalışmada sosyal sağlıkla birlikte ele alınan ve sosyal sağlık kazanım sürecinin tamamında yer alan bileşenlerden bir olan sosyal destek, diğer bileşenlerden -sosyal işlevsellik ve sosyal bütünleşme- ayrı olarak ele alınmaktadır. Bireye en yakın kurum olan aileye ve üyelerine sunulan sosyal desteğin sosyal sağlık kazanımı için rolleri belirlenmektedir. Çalışma böylelikle üç açıdan diğer çalışmalara eklemlenerek genelde sosyal bilim ve özelde sosyal hizmet literatürüne katkıda bulunacaktır.

- Sosyal sağlığın kapsamına temel bileşenlerle açıklık getirilmesi

- Sosyal sağlıkta ailenin destek rolünün irdelenmesi

- Bireysel/sosyal sorunların çözümünde sosyal sağlığın gerekliliğinin tartışılması

\section{Sağlık Medikal Boyutu Aşar}

Dünya Sağlık Örgütü (WHO, 1948)'nün tanımıyla sağlık; "Sadece sakatlık ya da hastalık durumunun olmayışı değil, fiziksel, zihinsel ve sosyal yönden tam bir iyilik halidir”. Bu tanımdan hareketle sağlığın sadece medikal/tıbbi boyuttan ibaret olmadı ̆̆ , aynı zamanda sosyal yönden de iyilik halini kapsadığı görülmektedir. Sağlığın sosyal yönden iyilik hali, sosyal sağlik terimiyle ifade edilmiş olup bireylerin, grupların ve toplumların birbiriyle olan iletişimlerinin ve etkileșimlerinin sağ lı̆̆ $1 /$ sağl1klı olma halini etkilemesi, bu terimin ilgi alanını oluşturmaktadır.

Sosyal sağllk terimi, toplumsal etkileşimin her seviyesininbireyden bireyler arası ilişkiye, bireyler arası ilişkiden toplumsal düzeydeki ilişkiye- sağlık üzerindeki etkisini nitelemektedir. Aynı zamanda sosyal sağlık, sağlığın kendi kendini iyileştirme potansiyelini en iyi şekilde gerçekleştirmesidir (Minkler, 1986: 34, 38). Buna ek olarak, literatürde sosyal sağlığa ilişkin yapılan tanımlar farklılık

${ }^{1}$ Bkz. Goldman, John J. (1990, 18 Ocak). Men's Death Rate Higher in Harlem Than Bangladesh. Los Angeles Times. (Erişim: 05.01.2020), https://www.latimes.com/archives/la-xpm-1990-0118-mn-336-story.html göstermektedir. Genel olarak sosyal sağlığa ilişkin yapılan tanımlar 3 türde ifade edilmiştir: 1) Bedensel (fiziksel) ve zihinsel sağlıkla birlikte ele alınan sosyal sağlık, 2) Sağlığın sosyal belirleyicileri olarak sosyal sağlık, 3) Sağlıklı bir toplum olarak sosyal sağlık (Abachizadeh vd., 2013: 88).

Elbette sağlık, medikal/tıbbi süreçlerden bağımsız değildir. Medikal/tıbbi açıdan sağlık, toplumsal eksenden çok birey/ler üzerinden değerlendirilmektedir. Medikal yaklaşım, fizyolojik-biyolojik açıdan yaşanan bazı rahatsızlıklara/hastalıklara ilişkin tedavileri tıbbi aletler ve doktorlar aracılığıyla sağlanmasını amaçlamaktadır (Marmot ve Wilkinson, 2006: 9-10). Engelliğe ilişkin medikal yaklaşım, bireysel sorunlara/kusurlara ve bireysel tedavilere odaklanmak için tasarlanmış profesyonel müdahaleleri içermektedir (Oliver, 1996: 10). Illich, bu profesyonel müdahalelerin insanları yalnızlaştırdığını ve hastalıklara/ eksiklere/ kusurlara odaklanarak çevresel ve kültürel koşulların ihmal edildiğini iddia etmektedir. Illich'e (2011: 14,16) göre tıp, insanları iyileştiren çevresel ve kültürel koşulları göz önünde bulundurmadan toplumdan rahatsız ve bıkkın olan insanları, hasta, güçsüz ve teknik onarım gerektiren kişiler olduklarına sınırsız yarar sağlama vaadinde bulunarak ikna etmeye yarayan bir araçtır.

"Sosyal sağlık" ise bireysel özellikleri çevresi içinde değerlendirerek tedaviden önce hastalığ önlemeyi uğraş edinen bir sağlık çerçevesi oluşturmaktadır. Bu sağlık çerçevesini de iki ölçütle belirler: 1) Bireyin sağlık durumunu aile gibi yakın çevresiyle değerlendirmek; 2) Bireyin sosyal destek mekanizmalarının iyileşme süreci için kullanmasını sağlamak.

\section{Sosyal Sağlığın Literatüre Girişi ve Uygulamaları}

Hastalığın bireylerdeki algısal değişimi ve Avrupa ülkelerinde son 30 yılda ortaya çıkan ömür beklentisindeki farklılıklar, sağlığın sosyal yönden kabulünü zorunlu kılmıştır. Toplumsal sistemin hiyerarşik yapısı -örneğin; Covid-19 pandemi sürecinde de çokça dile getirilen yoksulzengin bireylerin sağlık hizmetlerinden ne derecede yararlandığı-, insanların yaşamını idame ettirirken sahip olduğu şartlar, çalıştığ koşullar ve psikolojik faktörler ön plana çıkınca sağlığın sosyal organizasyonu şekillenmiştir. Sosyal organizasyona bağlı bireylerin yaşamış olduğu psikolojik sorunlar tahlil edilmeye çalışılmıştır. Örneğin stres 'bireyin bir başka birey tarafından uyarılmasıyla mı oluşmaktadır ya da bireyin toplumsal çevreye ilişkin biyolojik tepkisi midir?' sorusu ile değerlendirmeye tabi tutulmuştur (Marmot ve Wilkinson, 2006: 7-8). Şu veri toplumsal çevreye biyolojik tepki değerlendirmelerine bir delil hükmündedir: Harlem'de Afroamerikan erkeklerinin, çok yüksek yaşam standartlarına sahip olmasına rağmen yaşamış oldukları akut stresten dolayı ortalama ömürleri, Bangladeş'teki erkeklerden daha kısadır. ${ }^{1}$

Gittikçe sağlığın gözetilmesi ve hastalıkların önlenmesi adına sosyal faktörlerin rolünün desteklenmesinde çarpıcı bir artış görülmüş̧tür. Artan ilgi profesyonel sağlık çalışanları 
sahası ya da kendi-kendine yardım gruplarının etkinliği ile sınırlı kalmamıştır. Örneğin, aynı zamanda yalnızlığın ve bağışıklık sisteminin çöküşünün sağlık üzerindeki etkisi gibi konular bilimsel araştırmaların konusu haline gelmiştir. 1981'de California Ruh Sağlı̆̆ Servisi (Department of Mental Health), eyalet çapında "Arkadaşlar iyi ilaç olabilir" (Friends can be good medicine) kampanyası başlatmıştır. Devlet genelinde binlerce ajans ve topluluk temsilcileri, televizyon ve radyo spotlarıyla bilgilendirme yapmış; yerel sağlık bölümleri ve ajansları arkadaşlık ve sağlık konusunu ön plana çıkartmıştır (Minkler, 1986: 33). Bu etkinlikler yanında yapılan akademik araştırmalar da sosyal sağlığın boyutlarını genişletmiştir. Türkiye de araştırmaları ile katkı veren ülkeler arasındadır. Yükseköğretim Kurulu Başkanlığı Ulusal Tez Merkezi web sitesinde yapılan tarama neticesinde Hemşirelik Anabilim Dalına ait ulaşılabilen 2000 yüksek lisans ve 431 doktora tezinin araştırma konuları, medikal ve sosyal boyut yönünden incelendiğinde Tablo 1'deki sonuç ortaya çıkmıştır. Buna göre yüksek lisans tezlerinin $\% 20,5$ 'u ve doktora tezlerinin ise $\% 18,1$ 'i araştırmalarında sağlı̆̆ın sosyal boyutunu ele almaktadır. Yüksek lisans ve doktora tezlerinin tamamı değerlendirildiğinde, bu oran \%19,7'dir.

Tablo 1. Hemşirelik Anabilim Dalına Ait Tezlerin Konularının Medikal ve Sosyal Yönden Dağılımı

\begin{tabular}{lrrrrrr}
\hline \multirow{2}{*}{ Tezler } & \multicolumn{2}{c}{ Medikal Boyut } & \multicolumn{2}{c}{ Sosyal Boyut } & \multicolumn{2}{c}{ Toplam } \\
\cline { 2 - 7 } & \multicolumn{1}{c}{ Sayı } & \% & \multicolumn{1}{c}{ Sayı } & \% & \multicolumn{1}{c}{ Sayı } & \% \\
\hline Yüksek Lisans & 1599 & $\% 79,95$ & 401 & $\% 20,5$ & 2000 & $\% 100$ \\
Doktora & 353 & $\% 81,9$ & 78 & $\% 18,1$ & 431 & $\% 100$ \\
Toplam & 1952 & $\% 80,3$ & 479 & $\% 19,7$ & 2431 & $\% 100$ \\
\hline
\end{tabular}

Tezlerde ele alınan konular tasnif edildiğinde sosyal destek bağlamında gerçekleştirilen sosyal sağlık araştırmalarının, aile ve yakın çevreden sosyo-ekonomik yapıya, intihardan motivasyona kadar pek de dar olmayan bir çerçeve çizdiği görülmektedir. Genellikle şu konular üzerine araştırmalar yapılmıştır.

- Sosyal destek konusu ve özelinde ailenin/hasta yakınlarının sosyal desteği

- Sosyal ve ruhsal uyum düzeyleri ve hastal1klara ilişkin tıbbı tahlillerden ziyade psiko-sosyal, ruhsal durumlarının değerlendirilmesi

- Sosyo-demografik ve sosyo-ekonomik durumların sağlığa ve sağlık davranışlarına etkisi

- Anne-babaların özel bakım ihtiyacı olan çocuklarına yönelik kaygı durumları, yaşadıkları güçlükler ve başa çıkma stratejileri

- Annenin çocuğa bağlanma düzeyi

- Çalışanlarda, hasta bireylerde ve aile/hasta yakınlarında depresyon, stres ve anksiyete durumu

- Uğraş/müzik terapisinin anksiyete düzeyine etkisi

- Çalışanların iş doyumu, motivasyonu ve tükenmişliği

- Intihar ve algilanan sosyal destek

\section{Sosyal Sağlık Bileşenleri}

"Social Determinants Of Health: The Solid Facts" adl çalışmada, sağlığın sosyal bileşenleri 10 alanda ifade edilmiştir: 1) Sosyal değişim, 2) Stres, 3) Erken yaşam evresi, 4) Sosyal dişlanma, 5) İşyeri ortamı, 6) İşsizlik, 7) Sosyal destek, 8) Bağımlılık, 9) Beslenme, 10) Ulaşım. Bu bileşenler üzerinden bir tasnif yapıldığında, sosyal ve ekonomik koşullar (sosyal değişim, sosyal dişlanma ve işsizlik), psikolojik faktörler (stres, işyeri ortamı ve erken yaşam evresi) ve diğer faktörler (bağımlılık, beslenme, ulaşım) sağlığın sosyal belirleyicisi olarak yer almaktadır. Sosyal destek ise sosyo-ekonomik, psikolojik ve diğer faktörlerin ve dolayısıyla sosyal sağlığın genel bir bileşeni olarak ifade edilmektedir (Wilkinson ve Marmot, 2003: 1028).

Sosyal ve ekonomik koşullar: Elverişli olmayan sosyoekonomik koşullar, ciddi hastalıklara ve erken ölümlere sebep olabildiği gibi bireylerin sağlığını hayatı boyunca etkileyebilmektedir. Bununla birlikte yoksulluğun var olduğu yerlerde sosyal dişlanma ve ayrımcılık görülmektedir. Irkçılık, ayrımcılık, damgalama, karşıtlık ve işsizlik, sosyal dışlanmaya neden olabilmektedir. Bu durum ise uygun bir konutta yaşama, uygun bir işte çalışma, eğitim ve öğretime katılım gibi bireyin temel hizmet ve haklardan yararlanmasını engellemektedir.

Psikolojik faktörler: İşsizlik sağlık üzerindeki etkilerini psikolojik ve özellikle finansal açıdan göstermektedir. Bireylerin işsiz kalmadan önce çalıştıkları işyerlerinde yaşadıkları tehdit ve güvensizlik (işyerindeki yönetim tarzı ve sosyal ilişkilerle ilişkili olarak), bireylerde anksiyete ve depresyon gibi zihinsel hastalıkları arttırmakta ve dolayısıyla bireylerin sosyal sağlığına zarar verebilmektedir. Endişe, güvensizlik, düşük benlik saygısı, sosyal izolasyon, iş ve ev yaşamı üzerindeki kontrol eksikliği gibi psiko-sosyal yaşamsal riskleri ortaya çıkarmaktadır. Annelerin erken gelişim döneminde çocuklarına verdiği destek ve eğitim ise sağlıkta etkisini bir ömür sürdürmektedir. Çocukluk döneminde yavaş gelişme-büyüme ve zayıf kurulan duygusal destek, yaşam boyu fiziksel açıdan bireyin hastalık riskini arttırmakta ve yetişkinlik döneminde fiziksel, bilişsel ve duygusal işlevlerini azaltmaktadır. Bilişsel, duygusal ve duyumsal girdiler beyin tepkilerini programlarken, güvensiz duygusal bağlılık ve zayıf uyarılma yaşanırsa okul için eğitime hazır olmama, sorunlu davranışlara ve yetişkinlikte sosyal marjinalleşmeye neden olabilmektedir.

Diğer faktörler: Bireyler alkol, uyuşturucu ve sigara kullanımından bireysel olarak etkilenirler; ancak kullanım daha geniş anlamda sosyal alanı etkilemektedir. Uyuşturucu kullanımı hem sosyal açıdan bozulmaya hem de sağlıkta ortaya çıkan eşitsizliklerin kötüleşmesine zemin hazırlayan bir faktördür. Bireyler kötü sosyo-ekonomik koşulların ağrısını hissetmemek ve stresten kaçmak için uyuşturucu ve/veya alkol kullanmakta, sorunlardan kaçmaya çalışırken sorunlarını daha da arttırmaktadır. Diğer faktörler içinde yer alan beslenme ve ulaşım ise sosyal sağlıkta tam iyilik halini geliştirmek için merkezi konumdadırlar. Sağlıklı beslenme iyi bir diyet ve yeterli besin arzını nitelendirirken; sağlıklı ulaşım toplu taşımayla desteklenen daha az taşıt kullanımı ve daha fazla yürüyüş yapma ve bisiklet kullanımı anlamına gelmektedir. Bireyleri birbirinden izole eden otomobillerin aksine bisiklet, yürüyüş ve toplu taşıma, sokaklarda sosyal etkileşime zemin hazırlamaktadır. Bir yandan da azaltılmış yol trafiğiyle egzozdan kaynaklanan zararlı hava kirliliği oranları aşağıya çekilmektedir. 
Sosyal destek: Destek sistemi, bireylerin, sosyal ilişkilerini destekleyici olarak kabul ettiği ve sosyal bağların işlevsel ve yapısal yönden bağlamlarının harmanladığı bir terimdir. Sosyal destek kişisel ilişkilerin yürütülmesinden doğmakta ve bu ilişkiler, bireylerin kendi davranışlarına destekleyici bir anlam kazandırmaktadır (Gottlieb ve Bergen, 2010: 511512). İyi yapılandırılmış sosyal ilişkiler ve güçlü destekleyici ağlar, bireyin işyerindeki, evdeki ve toplumdaki sağlığını iyileştirmektedir. Sosyal destek, insanlara ihtiyaç duydukları duygusal ve pratik kaynakları sağlamaktadır. Sosyal iletişim ağı kuran ortak yükümlülükler, insanlara, kendilerini sevilen, saygın ve değer verilen olarak hissettirmektedir. Bu hissiyat sağl1kta güçlü bir koruyucu etkiye sahiptir (Wilkinson ve Marmot, 2003: 22).

Sosyal destek, bireylerin sağlıklı davranışların geliştirmesini kolaylaştırmakta, motive etmektedir. Uchino ve arkadaşları (1999: 146) bu konuda sigara örneğini aktarmaktadırlar. Yeterli sosyal desteğe sahip olduğu düşüncesi, kişinin sigarayı bırakma motivasyonunu arttırır ve daha sağlıklı davranışlar geliştirmesine katkıda bulunur. Dolayısıyla sosyal destek, duygusal desteği, gerektiğinde maddi desteği, tavsiye ve rehberliği içermektedir. Amaç bireylerin kimliğini korumak, benlik saygısını sağlamak, başetme kapasitelerini güçlendirmektir (Stamnes, 2000: 23). Özellikle sorunların çözümünde bireylere gerekli kaynakları sunma ve bireylerin başetme kapasitelerini güçlendirme vurgusu, sosyal sağlı̆̆ın kazanımında bireyleri sosyal işlevselliğe yönlendirmektedir.

Abachizadeh ve arkadaşları (2013: 88-92) İran'daki sosyal sağlığın temel ve alt alanlarını belirlemeyi amaçlayan bir araştırma yapmışlardır. 25 katılımcıyla gerçekleştirilen görüşme sonrasında ulaştıkları sonucu şöylece ifade etmişlerdir. Fiziksel ve zihinsel sağlık, diğer bileşenlerle (sosyal normlar, aile, arkadaşlar vs.) etkileşim halindedir. Bireysel sosyal sağlık, 'sosyal işlevsellik' ve 'sosyal destek' olmak üzere iki ana bileşene sahiptir. -Tablo 2'de ifade edildiği üzere- Sosyal sağlıkta sosyal işlevin 12 alt alanı ve sosyal desteğin ise 17 alt alanı bulunmaktadır.

Tablo 2. Sosyal Sağlığın Alanları ve Alt Alanları

\begin{tabular}{|c|c|}
\hline Sosyal İșlev & Sosyal Destek \\
\hline Finansal Destek & Hastalık \\
\hline Duygusal Destek & Engellilik \\
\hline Sosyal Gruplara Katılım & Gündelik Hayat Sorunları \\
\hline $\begin{array}{l}\text { Toplumun Karar Verme } \\
\text { Sürecine Katılımı }\end{array}$ & $\begin{array}{l}\text { Aile Üyelerinin veya Arkadaşların } \\
\text { Ölümleri }\end{array}$ \\
\hline Aile Üyeleriyle İlgilenme & Başarılı Evlilik \\
\hline Arkadaşlarla İlgilenme & Duygusal Sorunlar \\
\hline $\begin{array}{l}\text { Hastaların Bakımını } \\
\text { Üstlenme }\end{array}$ & İş Arama \\
\hline $\begin{array}{l}\text { Günlük Ev İşlerine Yardımcı } \\
\text { Olma }\end{array}$ & Gelir Elde Etme \\
\hline Çevreyi Koruma & Eğitim \\
\hline $\begin{array}{l}\text { Sosyal Normlara Sayg1lı } \\
\text { Olma }\end{array}$ & Şiddete Karşı Güvenlik \\
\hline Bağış Programlarına Katılma & Sevgiyi İfade Etme \\
\hline \multirow[t]{6}{*}{ Başkalarına Güvenme } & Kanunları Destekleme \\
\hline & Manevi ve Tinsel Destek \\
\hline & Bireysel Takdir \\
\hline & $\begin{array}{l}\text { Bireyi Toplum Üyesi Olarak } \\
\text { Kabul Etme }\end{array}$ \\
\hline & Bireysel Sayg1 \\
\hline & Eğlence Olanaklarına Erişim \\
\hline
\end{tabular}

Kaynak: Abachizadeh vd. (2013: 90)
Tablo göstermektedir ki sosyal destek, toplumsal refahı ve sosyal sağlığı koruyan bir kaynak oluşturmaktadır. Lindström'in (2008: 216) ifadesiyle de sosyal destek, hem kişilerarası bağlantıları şekillendirmekte hem de kişilerarası ilişki ve etkileşimlerin toplum nezdinde kabul edilmesini ve sosyal sağlığı geliştirici davranışların benimsenmesini sağlamaktadır.

'Bazı bireyler neden diğer bireylerden daha fazla hasta olma eğilimindedirler?' sorusuna cevap bulmak araştırmacıların meşguliyeti içerisine girmiştir. Ortak çıkan sonuçları Stamnes (2000: 23) şöylece belirlemektedir. Stresli sosyal ortamlar, davranışlarda ve sağlık durumunda değişikliklere sebep olmaktadır; stres faktörleri, hastalığa karşı genel duyarlılığ1 arttırmaktadır; bireyler için bir "tampon" olan sosyal desteğin eksikliğinde ise hastalık riskleri ortaya çıkabilmekte ve rehabilitasyon süreci engellenebilmektedir. Örneğin; sosyal destek ve bağışıklık sistemi ilişkisini belirlemeye yönelik 19 araştırmayı inceleyen Uchino vd. (1999: 146-147), sosyal destek ve bağışıklık arasında doğru orantılı bir ilişkinin varlığını ortak bir sonuç olarak belirlemişlerdir. Zira bağışıklık sistemi, bedenin bulaşıcı ve kanserli hastalıklara karşı savunmasında etkili olmaktadır. Yüksek düzeyde sosyal desteğe sahip bireylerin, daha düşük sosyal desteğe sahip bireylerden daha güçlü bağışıklık sistemine sahip olduğu da ortaya çıkmıştır.

Cohen (2004: 676-677) sosyal desteği sosyal ağ ile ifade eder. Kişinin stresle başetme yeteneğini kazandırma amacıyla psikolojik ve maddi kaynaklar üzerinde sosyal ağın kurulmasıdır. Başka deyişle sosyal destek, sosyal ortamlarda ve sosyal ağlar içerisinde etkisini göstermektedir. Bu ağlara dâhil olan bireyler ilişkilerini güçlendirerek sosyal yaşantılarını uygun koşullarda ve sağlıklı bir sosyal çevrede sürdürmektedir. Sağlıklı olma/olabilme ihtiyacı ise daha çok sağlığı etkileyebilen sosyal destek mekanizmaları ile karşılanmaktadır. Sosyal destek kapasitesini güçlendirmek için motivasyonel faktörler önemini korumaktadır (Stamnes, 2000: 26-27). Bireylere, gerekli bu motivasyonu sağlayan en temel sosyal kurum/birim ya da en yakın çevre ise aile ve ailenin sunmuş olduğu sosyal destektir. Aileler, bireylerin başetme kapasitelerini ya da savunma mekanizmalarını güçlendirmesinde ve sağlığın bütüncül -hem fiziksel hem sosyal- olarak korunmasında gerekli kaynakları sunmaktadır.

\section{Sosyal Sağlıkta Ailenin Desteği}

Sosyal sağlık için gerekli kaynaklar "sosyal güçler" tarafından sağlanmaktadır. Bu güçler kaynağı, bir sosyal grubun üyeleri arasındaki ilişkilerin içerisinde bulunmakta ve dolayısıyla bireyler arasında gerçekleşen etkileşim de kaynak üretimini sağlamaktadır. Bir sosyal sistemin sürdürülebilirliğini sağlamak için gerekli etkileşim ise sosyal sağlığın temellerini oluşturmaktadır (Smith, 1982: 363).

Sosyal destek, doğuştan itibaren bir annenin kendi bebeğine destek sunmasıyla başlamaktadır. Sosyal yaşam alanı genişledikçe sosyal destek sınırları da genişlemektedir. Akrabalar, arkadaşlar, iş arkadaşları, sosyal ve sağlık alanında çalışan profesyoneller, ..., toplum. Yaşamın sonuna yaklaşınca da -kültürel etkenlerin de etkisiyle- bireylere sunulan sosyal destek yine büyük ölçüde aile üyeleriyle sağlanmaktadır. O nedenle ailenin sosyal açıdan iyilik hali, bir yandan sosyal destek sunumunu kolaylaştırırken bir 
yandan da ulusal olarak sosyal dayanışmayı güçlendirmekte ve dolayısıyla toplumsal refaha katkı sağlamaktadır.

Ulusal ekonomik kalkınmanın sağlanmasında ve sosyal dayanışmanın güçlendirilmesinde sosyal iyilik hali, toplumsal sorumlulukların ortak paylaşımlarını oluşturur (Jakab, 2011, 3-5). Bireyler, sosyal iyilik halini kişisel zaman ile sosyal zamanı dengeleyerek ve diğer bireylerle etkileşime girerek gerçekleştirmektedir. Bu süreçte sosyal destek, en etkin biçimde kendini, bireyin aile ve yakın çevresi ile sosyal ağlarını sürdürmesinde ve geliştirmesinde gösterir. Smith'in (1982: 364) deyişiyle, çoğu birey için ilk sosyal ilişkiler aileseldir; bu nedenledir ki sosyal ilişkilerin doğasını anlamak için aile ilişkileri incelenmektedir. İlişkilerinin yapısı, roller, cinsiyet, yaş vb. açılardan farklı farklı ailelerde sosyal ve psikolojik koşullardan etkilenebilen sosyal güçler mevcuttur. Bu güçler sosyal iyilik halinin temel taşlarıdır. Thanakwang ve Soonthorndhada (2011: 13651370) 469 Taylandlı yaşlı ile yaptıkları araştırmada bu güçlere arabulucu konumu yüklemektedirler. Araştırmada hem aile hem de arkadaşlık destek ağlarının sağlıklı olmayı teşvik eden davranıșları etkilediği; bu desteklerin öncelikle aile ve arkadaşlık ağları yoluyla aktarıldığı; bu destek mekanizma ve ağlarının "arabulucu” konumda bulunduğu ifade edilmiştir.

Anlaşılacağı üzere sağlığın sosyal bileşenleri de -kültürel etkenler göz önünde bulundurulduğunda- bireylerin ve toplumların sağlıklı olma hallerini etkileyen sosyal ve çevresel güçler olarak kabul edilmektedir ki sosyal bileşenler, politik sistemler, kaynaklar gibi değer sistemleri ve aile aracılığıyla şekillenmektedir. Aileler, aile üyeleri için sosyalleşme ve koruma işlevlerini yerine getirdikçe, potansiyel aile sağlığını ve dolayısıyla toplumun sosyal sağlığını muhafaza edebilmektedir (Deatrick, 2017: 423, 426). Bu bağlamda sosyal sağlık, esasta bir kişinin sosyal destek sistemlerinin kapsamına odaklanır ve bunların fiziksel ve zihinsel yönden sağlığı etkilediğini savunur (Larkin, 2011: 245). Bu etkiyi ortaya koyan çalışmalardan biri, Carlson ve arkadaşlarının (2002: 733) yaptıkları araştırmadır. 557 kadın ile yapılmış araştırmada, depresyon yaşayan kadınların \%33,3'ünün, depresyon yaşamayan kadınların ise \%84,1'inin sosyal desteğe sahip oldukları saptanmıştır.

Sanayileşmeyle birlikte artan göç ile nüfusun büyük kısmı, kırsal alanlardan kentsel alanlara, küçük şehirlerden büyük şehirlere ve hatta nüfusun bir kısmını da bir ülkeden diğer bir ülkeye doğru bir hareketlilik yaşamıştır. Oluşan yeni sosyal çevre, geleneksel ve modern toplum ayrımında, ailelerin rol ve işlevlerine farklı/çeşitli boyutlar kazandırmıştır. Modern toplumda yer alan kurumlar arasındaki iş bölümü de oldukça farklıdır. Artık aileler, üyelerinin ihtiyaçlarını karşılamak için geleneksel toplumda olduğundan daha fazla karmaşık bürokratik kurumlara güvenmek zorundadır. Ancak bir aile, bürokratik kurumlar dâhil dışarıdan gelen yardım ve destekle sorununa (hastalık, işsizlik vb.) çözüm getiremediği durumda, bu sorunu çözmek için ne yapabilir? (HaavioMannila, 1976: 325). Öte yandan, kadınların istihdamının sağlanmasına rağmen, ev ve ailedeki geleneksel rolleri ve sorumlulukları değişmemiştir. Artık hem işteki hem evdeki rolleriyle aşırı bir yük kaynağına sahip olan kadınlar, rollerin çeşitliliğine ilişkin talepleri dengelemeye çalışmaktadır. Bu talepler dengelenemediğinde ise stres ortaya çıkmakta ve dolayısıyla hem kadına hem de aileye krizler yaşatmakta ve baskı unsurlarına sebep olabilmektedir (Asnani vd., 2004: 132-133). İşte bu modernleşme sonrası ortay çıkan yeni aile yapısında bahsi geçen sorun ve baskı unsurlarıyla mücadele edebilmek için ailelerin bir sosyal sağlık bileşeni olarak sosyal destek mekanizmalarını ne ölçüde sunabildikleri ve/veya kullanabildikleri önem kazanmaktadır.

Bireylerin karşılaştıkları sorunlara yönelik kullanacakları sorun ve duygu odaklı başa çıkma stratejileri bulunmaktadır. Bunları bireyler hem kullanır/uygular hem de diğer bireylere önerirler. Esasen sosyal destek, başa çıkma desteğidir. Başa çıkma desteği, sıkıntı yaşayan bireyin durumu farklı bir şekilde görmesine yardım etmeyi, sorunları çözmenin yollarını önermeyi, doğrudan duruma müdahale etmeyi, kişiyi cesaretlenmeyi/güçlendirmeyi içerir. Aynı zamanda stres tamponlarına sahip, stres yaratan faktörlerin fiziksel ve psikolojik sonuçlarını ve duygusal tepkilerini azaltan ve kişilerin durumu kontrol edebilme duygusunu destekleyen stratejileri içermektedir (Thoits, 2011: 152). Bireyin sorunla başa çıkması için bu öneri, müdahale ve stratejilerde etkin rol alanlar özellikle yakın çevresidir -aile, akraba ve arkadaşları-. Yakın çevre stres, depresyon vb. faktörlerin zararlı etkilerini azaltmak için fiziksel, duygusal, psikolojik ve finansal yardım sunarlar. Ancak sunulan destek, sorunlar ile başa çıkmada teşvik edici olsa da sorunları çözmede yeterli gelemeyebilir. Yine bireyin yakın çevresi yaşanılan sorunlara ilişkin psikolojik ve duygusal sorunlar yaşayabilir ve sosyal desteğe ihtiyaç duyabilir. Bu bağlamda, soruna odaklanmak yerine, sorunu çözebilecek mekanizmayı da güçlendirmek gerekebilir. $\mathrm{O}$ nedenle aileler başta olmak üzere bireyin yakın çevresine de sosyal destek sunulur ki, bu destek bireylerin baş etme kapasitelerini arttırmaktadır.

Romatizma hastalığına sahip hastalarla yapılan araştırmada sosyal destek kaynağının oranları verilmiştir. Hastalar, en yüksek oranda desteği \%52,2 ile aileden almaktadır (Brooks vd., 2014: 23-25). Bu yönüyle ve temelde aile olmak üzere sosyal destek, bireylerin hastalıklarına yönelik gerekli bakımının sağlanmasında, kronik hastalığının iyileşmesinde etkin rol oynamaktadır. Sosyal destek, bireylerin sağlık süreçlerine katılımını sağlayarak yaşamlarının dinamik bir yönünü oluşturmaktadır. Florian ve Krulik (1991: 1294) kronik hastalığı olan çocukların annelerinin yalnızlık ve sosyal destek düzeylerini ele alan bir araştırma yapmışlardır. Ulaşılan sonuç şudur: Kronik hastalığı olan çocukların anneleri, sağlıklı çocuğa sahip annelere göre daha düşük sosyal desteğe sahip olup daha yüksek düzeyde yalnızlık yaşamaktadırlar. Nedenini anlamak için çok çabalamaya da gerek yoktur. Zira kronik hastalığı olan çocuğuna uzun süre bakımını üstlenen annenin fiziksel, duygusal ve sosyal sağlığının etkilenmesi beklenen durumdur. Annelerin uzun süre yaşamış olduğu bakım yükünü hafifletebilmek için ise var olan etkili kaynak, yine sosyal destektir. Hem annenin hem anneye bağımlı olan çocuğun sağlığ 1 , annenin sosyal sağlığının durumuna bağlıdır. Sosyal destek ihtiyacı özelde tüm dezavantajlı gruplar için geçerlidir. Örneğin, bakıma ihtiyacı olan bireyler arasında yer alabilen yaşlılar için de durum aynıdır. Yaşamını devam ettirebilmesi ve sosyal iyilik halinin sağlanması için aile üyelerinin sosyal desteği önemli olabilmektedir. Reinhardt'ın (1996: 275) yaşa bağlı görme kaybı yaşayan 241 yaşlının adaptasyonunda, aile ve arkadaş desteğinin önemini belirlemeye yönelik araştırmasında, enstrümantal yardım, rehberlik, dostluk, değerli hissetme, toplumsal bütünleşme ve manevi ilgi olmak üzere altı bileşene bakılmıştır. Buna göre, toplumsal bütünleşme hariç 
aile desteğinin arkadaş desteğinden anlamlı olarak daha yüksek olduğu ortaya çıkmıştır.

Örnek çalışmalar göstermektedir ki aile sistemi, sosyal sağlığın sağlanmasında temel bir işleve sahiptir ve işlevlerini sosyal destek mekanizmaları kullanarak güçlendirmektedir. Ailelerin sosyal sağlık bileşenlerini ise Smith'in (1982: 364366) dile getirişiyle duygusal bağ, davranışsal değer sistemi, sosyo-kültürel yapı ve roller, etkili bir ilişki oluşturmaktadır.

a) Duygusal bă̆: Aile üyeleri arasında ilişkilendirilen duygusal bağ, fiziksel ve psikolojik etkenlerden çok sosyo-davranışsal ve sosyo-kültürel koşullarla oluşmaktadır.

b) Davranışsal değer sistemi: Sosyalleştirilmiş insan davranışı, genellikle bilinçsiz bir şekilde çalışan ve ifadesi sözel olmaktan ziyade eylemsel olan bir değer sistemi tarafından yönetilmektedir. Sosyal uyum ve dayanışma ise uygun davranışsal değer sistemini yaratmaktadir.

c) Sosyo-kültürel yapı ve roller: Ailenin yapısı, sosyokültürel yapı tarafından belirlenmektedir. O yüzden ataerkil, anaerkil gibi birçok farklı aile biçimlerinin tanımları ve ilişki yapıları farklılaşmaktadır. Bu yapılar, kültüre bağlı olarak değişen rollere sahiptir.

d) Etkili bir ilişki: Etkili bir ilişki için rollerin açıkça tanımlanmasına ve uyumlu bir değer sistemine ihtiyaç vardır. Örneğin; -sosyo-kültürel ortamdan bağımsız düşünmemek kaydıyla-, bebek bakımına ilişkin uyumlu bir değer sistemi geliştirebilir. Ama önce ebeveynlerin sorumluluklarının belirlenmesi; sorumlulukların belirlenebilmesi için de rollerinin açıkça tanımlanması gerekmektedir.

\section{Sonuç}

Toplumsal hayatta sağlık, sadece medikal ve tıbbi açıdan sağlıklı ya da hasta olup olmama, iyileşme-iyileşememe vb. durumlarla sınırlı değildir. Sağlığın biyolojik/fiziksel yönü kadar psikolojik ve sosyal yönü de mevcuttur. Aile, akraba, arkadaş gibi sosyal destek mekanizmaları ile birlikte ele alındığında sağlık, "sosyal sağlık" kavramı ile ifade edilir. Ancak literatürde ortak bir tanımı bulunmayan sosyal sağlık denince Türkiye'deki kaynaklarda genelde sosyal hekimlik, toplum hekimliği ve toplum sağlığı; batılı kaynaklarda ise genellikle sağlığın sosyal bileşenleri üzerinde durulmaktadır ki bileşenlerden birisi de sosyal destektir. Bu çalışmada da sosyal sağlık kazanımında aile üyelerinin sunduğu ve kendilerine sunulan sosyal desteğin rolleri belirlenmektedir.

Çalışma sağlığın, medikal/tıbbi boyutla birlikte sosyal yönden de iyilik halini kapsadığını; iyileşme sürecinde aile vb. yakın çevresi içinde sosyal destek mekanizmalarını harekete geçirerek tedaviden önce hastalığı ve nedenlerini önlemeyi uğraş edinen bir sağlık çerçevesi oluşturduğunu ortaya koymaktadır. Bu çerçevede sosyal sağlığın literatüre giriş ve uygulamalarından örnekler vermektedir. Covid-19 pandemi sürecinde sağlık hizmetlerinden yoksul ile zengin bireylerin yararlanma imkânları ve yine yaşam standartları ile ömür arasındaki ilişki üzerinden sağlığın sosyal organizasyonunun şekillenişi gibi. Böylece başlatılmış olan "arkadaşlar iyi ilaç olabilir" kampanyası ve yine Hemşirelik Anabilim Dalında yürütülen tezlerin $1 / 5$ 'inin sağlığın sosyal boyutunu ele alınması örneğinde olduğu gibi, sağlığın gözetilmesi ve hastalıkların önlenmesi için sosyal faktörlerin rolünün desteklenmesinde bir artış görüldüğü sonucuna ulaşılmıştır.

Çalışma, on alanda sağlığın sosyal bileşenlerini; bileşenler üzerinden sosyal ve ekonomik, psikolojik ve diğer faktörler sınıflamasıyla sağlığın sosyal belirleyicilerini ve sağlıkta koruyucu ve iyileştirici etkiye sahip destekleyici ağların gücünü ortaya koymaktadır. Sosyal sağlıkta sosyal işlevin 12 ve sosyal desteğin de 17 alt alanı bulunduğu belirleyen araştırmayı dayanak alarak çalışma, başetme kapasitesi vurgusunun bireyleri sosyal işlevselliğe yönlendirdiği ve sosyal desteğin toplumsal refahı ve sosyal sağlığı koruyan bir kaynak oluşturduğu ve bireyler için bir tampon görevi gördüğü sonucuna ulaşmaktadır. Bu bağlamda sosyal sağlık için gerekli kaynaklar içinde etkin bir sosyal güç olarak akraba ve arkadaşların ve nihayet toplumun oynadığı rol yanında özelde ailenin rolü delilleriyle ele alınmaktadır. Ulaşılan sonuç ise bireylere sunulan sosyal desteğin büyük ölçüde aile üyeleriyle sağlandığıdır ki; ailenin sosyal açıdan iyilik halinin sosyal destek sunumunu kolaylaştırırken ulusal olarak sosyal dayanışmayı güçlendirip toplumsal refaha katkı sağladığıdır. Aile ile birlikte diğer tüm yakın çevre ağlarının arabulucu konumda bulunduğudur.

Modern toplum olma sonrasında ailelerin, ihtiyaçlarını karşılamak için bürokratik kurumlara güvenmek zorunda kalışlarından; kadınların rol çeşitliliğine ilişkin talepleri dengeleme çabalarından; yine göçler açısından bakıldığında da bireylerin sorunlarla karşı karşıya kalışlarından hareketle ailenin sosyal destek mekanizması olarak önem kazandığı görülmektedir. Başa çıkma desteği olarak sosyal destekte etkin rol alanlar çeşitli yardım sunmalarıyla özellikle bireyin yakın çevresidir. O nedenle çalışmada sağlıklı sosyal yaşam için soruna odaklanmak yerine sorunu çözebilecek mekanizmayı güçlendirmenin gerekliliği ortaya çıkmaktadır. Zira aile sistemi, sosyal sağlığın sağlanmasında temel bir işleve sahiptir. Konuya ilişkin yapılan araştırmalarda da

- Hem aile hem de yakın çevredeki ağların sağlıklı olmayı teşvik eden davranışlar geliştirdiği,

- Depresyon gibi sağlığı olumsuz yönden etkileyen psikolojik faktörlerin sosyal destek ile çözülebildiği ya da sosyal desteğe sahip olmanın bir ilaç etkisi yaratabildiği,

- Destek mekanizmaları olarak arabulucu olabildiği,

- Sosyal iyiliğe ilişkin gerekli kaynakları sunabildiği görülmektedir.

$\bullet$

\section{Kaynakça}

Abachizadeh, K., Omidnia, S., Memaryan, N., Nasehi, AA., Rasouli, M., Tayefi, B. \& Nikfarjam, A. (2013). Determining dimensions of Iranians' individual social health: A qualitative approach. Iranian J Publ Health, 42(1), 88-92.

Asnani, V., Pandey, U. D., \& Sawhney, M. (2004). Social support and occupational health of working women. Journal of Health Management, 6(2), 129-139. https://doi.org/10.1177/097206340400600204 
Brooks, A. T., Andrade, R. E., Middleton, K. R., \& Wallen, G. R. (2014). Social support: A key variable for health promotion and chronic disease management in Hispanic patients with rheumatic diseases. Clinical Medicine Insights: Arthritis and Musculoskeletal Disorders, 7, https://doi.org/10.4137/CMAMD.S13849

Carlson, B. E., McNutt, L.-A., Choi, D. Y., \& Rose, I. M. (2002). Intimate partner abuse and mental health. Violence Against Women, 8(6), 720-745. https://doi.org/10.1177/10778010222183251

Cohen, S. (2004). Social relationships and health. American $\begin{array}{lll}\text { Psychologist, } & 59(8), & 676-684\end{array}$ https://doi.org/10.1037/0003-066X.59.8.676

Deatrick, J. A. (2017). Where is "family" in the social determinants of health? Implications for family nursing practice, research, education, and policy. Journal of Family Nursing, 23(4), 423-433. https://doi.org/10.1177/1074840717735287

Florian, V., \& Krulik, T. (1991). Loneliness and social support of mothers of chronically ill children. Social Science \& Medicine, 32(11), 1291-1296. https://doi.org/10.1016/0277-9536(91)90045-E

Gottlieb, B. H., \& Bergen, A. E. (2010). Social support concepts and measures. Journal of Psychosomatic Research, 69(5), 511-520. https://doi.org/10.1016/j.jpsychores.2009.10.001

Haavio-Mannila, E. (1976). Social linkages used by migrant and nonmigrant families in solving health, work and economic problems. Acta Sociologica, 19(4), 325-348. https://doi.org/10.1177/000169937601900403

Illich, I. (2011). Sağlı̆̆ın gaspl. (S. Sertabiboğlu, Çev.). İstanbul: Ayrıntı Yayınları.

Jakab, Z. (2011, October), Designing the road to better health and well-being in Europe. 14th European Health Forum Gastein, Austria. (Erişim: 02.12.2019), http://www.euro.who.int/_data/assets/pdf_file/0003/15 2184/RD_Dastein_speech_wellbeing_07Oct.pdf

Larkin, M. (2011). Social aspects of health, illness and healthcare. Maidenhead: Open University Press.

Lindström, M. (2008). Social capital and health-related behaviors. I. Kawachi, S. V. Subramanian \& D. Kim
(Ed.), Social capital and health içinde (ss. 215-238). New York: Springer.

Marmot, M. \& Wilkinson, R. (2006). Social determinants of health. New York: Oxford University Press.

Minkler, M. (1986). The social component of health. American Journal of Health Promotion, 1(2), 33-38. https://doi.org/10.4278/0890-1171-1.2.33

Oliver, M. (1996). Understanding disability: From theory to practice. London: Macmillan Education.

Reinhardt, J. P. (1996). The importance of friendship and family support in adaptation to chronic vision impairment. The Journals of Gerontology Series B: Psychological Sciences and Social Sciences, 51B(5), P268-P278. https://doi.org/10.1093/geronb/51B.5.P268

Smith, J. R. P. (1982). Social health concepts for family practice. Social Casework, 63(6), 363369. https://doi.org/10.1177/104438948206300606

Stamnes, J. H. (2000). Social support, social network and health: Presentation of findings, and integration of accumulated knowledge in the the clinical field. Nordic Journal of Nursing Research, 20(4), 23-27. https://doi.org/10.1177/010740830002000405

Thanakwang, K. \& Soonthorndhada, K. (2011). Mechanisms by which social support networks influence healthy aging among Thai community-dwelling elderly. Journal of Aging and Health, 23(8), 1352-1378. https://doi.org/10.1177/0898264311418503

Thoits, P. A. (2011). Mechanisms linking social ties and support to physical and mental health. Journal of Health and Social Behavior, 52(2), 145-161. https://doi.org/10.1177/0022146510395592

Uchino, B. N., Uno, D. \& Holt-Lunstad, J. (1999). Social support, physiological processes, and health. Current Directions in Psychological Science, 8(5), 145-148. https://doi.org/10.1111/1467-8721.00034

WHO. (1948). (Erişim: 03.01.2019), https://www.unh.edu/health-services/ohep/socialwellness

Wilkinson, R. \& Marmot, M. (Ed.). (2003). Social determinants of health: The solid facts. Copenhagen: World Health Organization. 


\section{Extended Abstract}

The health includes all of physical, psychological and social components. Social life is discussed by researchers in terms that include "social", such as the social well-being of the individual and society in general, social support, social functionality. In this context, the acceptance of the bio-psycho-social existence of humans necessitates the consideration of health not only from a biological / physical perspective, but also psychologically and socially. The importance of the medical is seen in the improvement of the illnesses of individuals and in finding tools such as drugs that can treat their illnesses. However, in addition to the biological / physical treatment of the disease with drugs, the existence of social support mechanisms such as family, relatives, friends in this life process for individuals is not ignored. Health goes beyond the medical dimension, and the concept of "Social Health" is a product of this idea.

The perceptual change of the disease in individuals and the differences in life expectancy in the last 30 years in European countries have made social acceptance of health necessary. The social organization of health has been shaped when the hierarchical structure of the social system, the conditions people have while maintaining their lives, working conditions and psychological factors come to the fore. Psychological problems experienced by individuals linked with the social organization have been tried to be analyzed. There has been a dramatic increase in supporting the role of social factors on behalf of the observance of health and disease prevention. The increasing attention has not been limited to the field of professional healthcare professionals or the effectiveness of self-help groups. As $19.7 \%$ of the 2000 master's and 431 doctoral -accessibletheses belonging to the Department of Nursing at Turkey deal with the social dimension of health.

There is no common definition of social health in the literature. In general, definitions of social health are expressed in three types: 1) Social health, which is considered together with bodily (physical) and mental health, 2) Social health as the social determinants of health, 3) Social health as a healthy society. That can be said that definitions have two common points: 1) Social health includes the complete well-being of individuals, groups and society; 2) It is the determination of the tools / focuses used in realizing well-being. These tools are social support, social functionality, social integration, which provide gains in the individual focus on solving problems and strengthening the capacity to cope with problems. Thus, "Social Health" creates a health framework that tries to prevent the disease and its causes before treatment by evaluating individual characteristics within its environment. It determines this health framework with two criteria: 1) Evaluating the health status of the individual with his / her immediate environment such as family; 2) To enable the individual to use social support mechanisms for the healing process. Within the framework of these definitions and criteria, the social components of health are expressed in the following 10 areas: 1) Social change, 2) Stress, 3) Early life stage, 4) Social exclusion, 5) Workplace environment, 6) Unemployment, 7) Social support, 8) Addiction, 9) Nutrition, 10) Transportation. When a classification is made on these components, social and economic conditions (social change, social exclusion and unemployment), psychological factors (stress, workplace environment and early life stage) and other factors (addiction, nutrition, transportation) are included as social determinants of health. Social support is expressed as a general component of socio-economic, psychological and other factors and therefore social health.

In this study, social support, which is one of the components of the entire social health acquisition process, is considered separately from other components (social functionality and social integration). The roles of the social support offered to the family and members, the institution closest to the individual, for social health gain are determined. The family, which is considered as the building block in the maintenance of social relations and interactions, continues its duty as an intermediary institution. The study aims to determine the position of the family as an effective actor in providing social well-being and / or protecting social health by using their capacity to cope with social problems. Therefore, it draws attention to the value of social support, which is a component of social health, in the family institution.

Considering cultural factors, the social components of health are considered as social and environmental forces that affect the health of individuals and societies. These social components are shaped through value systems such as political systems and family. Studies show that the family system has a fundamental function in providing social health and strengthens its functions by using social support mechanisms. The social health components of families are emotional ties, behavioral value system, socio-cultural structure and roles which creates an effective relationship. Because social support starts with a mother's support to her baby from birth. As the social life area expands, the limits of social support also expand. Relatives, friends, colleagues, social and health professionals,..., society. Social support offered to individuals as they approach the end of their lives - also with the effect of cultural factors - is again provided mostly by family members. For this reason, the social well-being of the family facilitates the provision of social support, on the other hand, strengthens social solidarity nationally and thus contributes to social welfare. As families fulfill their socializing and protecting functions for family members, they can preserve potential family health and therefore the social health of the community.

The study was carried out using discourse analysis method. Literature studies in the field of social health and social support were examined and the level of relationship in the family context was revealed.

The study states that a) social support is an effective tool for social health, which plays a role in achieving the full well-being of individuals, strengthening their coping capacities and achieving their social functionality; b) the social support provided by the family or family members is the address of the most effective contribution to social health; c) reached the conclusion that the family and all other nearby networks are in a mediator position. As such, the study will contribute to social science in general and social work literature in particular in three aspects. Clarifying the scope of social health with basic components; examining the family's support role in social health and discussing the necessity of social health in solving individual / social problems. 